\title{
Evaluation of peak flow and symptoms only self management plans for control of asthma in general practice
}

\author{
Ian Charlton, Gillian Charlton, Judy Broomfield, Mark A Mullee
}

\begin{abstract}
Objective-To compare a peak flow self management plan for asthma with a symptoms only plan.

Design-Randomisation to one of the self management plans and follow up for a year.

Setting-Four partner, rural training practice in Norfolk.

Subjects - 115 Patients (46 children and 69 adults) with asthma who were having prophylactic treatment for asthma and attending a nurse run asthma clinic.

Main outcome measures-The number of doctor consultations, courses of oral steroids, and short term nebulised salbutamol treatments and the number of patients who required doctor consultations, courses of oral steroids, and short term nebulised salbutamol.

Results-Both self management plans produced significant reductions in the outcome measures but there were no significant differences in the degree of improvement between the groups. The results were similar for children and adults. The proportions of patients requiring a doctor consultation fell from $98 \%(50 / 51)$ to $66 \%(34 / 51)$ in the peak flow group and from $97 \%(62 / 64)$ to $53 \%(34 / 64)$ in the symptoms only group and the proportions requiring oral steroids from $73 \%(34 / 46)$ to $47 \%(21 / 46)$ and $52 \%(31 / 60)$ to $12 \%(7 / 60)$. The median number of doctor consultations was reduced from 8.0 to 2.0 in the peak flow group and from 4.5 to 1.0 in the symptoms only group.
\end{abstract}

Conclusions-The peak flow meter was not the crucial ingredient in the improved illness of the two groups. Teaching patients the importance of their symptoms and the appropriate action to take when their asthma deteriorates is the key to effective management of asthma. Simply prescribing peak flow meters without a system of self management and regular review will be unlikely to improve patient care.

Aylsham, Norfolk

Ian Charlton, MRCGP, trainee assistant

Gillian Charlton, RGN, practice nurse

Judy Broomfield, RGN, practice nurse

Medical Statistics and Computing, University of Southampton

Mark A Mullee, MSC, senior

faculty statistical programmer

Correspondence to:

Dr Charlton, Primary

Medical Care, University of

Southampton, Aldermoor

Health Centre,

Southampton SO1 6ST.

BrMed f 1990:301:1355-9

\section{Introduction}

The use of peak flow meters in general practice has been well described, particularly in the diagnosis and assessment of asthma. ${ }^{1-3}$ The issuing of the comparatively cheap and accurate mini-Wright peak flow meter ${ }^{4}$ has been advocated as worthwhile for patients with asthma, ${ }^{5}$ and pressure has been growing to make such meters available on prescription, ${ }^{6}$ as is already the case in New Zealand. Few studies have looked at issuing peak flow meters to patients for use in the day to day management of their asthma. Studies have highlighted the fact that up to a fifth of patients are unable to gauge the severity of their asthma despite appreciable deterioration in their lung function. ${ }^{78} \mathrm{~A}$ peak flow meter would seem to be invaluable to such patients.
Recent studies have shown considerable success

\section{Peak flow self management plan} What to do and when

- If peak flow greater than $70 \%$ of normal Continue maintenance treatment:

(a) Bronchodilator two times a day or when needed

(b) Inhaled steroid two times a day

- If peak flow less than $70 \%$ of normal

(1) Double dose of inhaled steroid for number of days required to achieve previous baseline

(2) Continue on this increased dose for same number of days

(3) Return to previous dose of maintenance treatment

- If peak flow less than $50 \%$ of normal

(1) Start oral prednisolone $40 \mathrm{mg}$ daily $(20 \mathrm{mg}$ daily for children) and contact general practitioner

(2) Continue on this dose for the number of days required to achieve previous baseline

(3) Reduce oral prednisolone to $20 \mathrm{mg}$ daily

( $10 \mathrm{mg}$ daily for children) for same number of days

(4) Stop prednisolone

- If peak flow less than $30 \%$

(1) Contact general practitioner urgently or, if unavailable,

(2) Contact ambulance or, if unavailable,

(3) Go directly to hospital

FIG 1-Peak flow self management plan adapted from Beasley et al"

when patients are given self management plans. ${ }^{9}$ The aim of this study was to evaluate the role of peak flow meters in such a plan and to find out the effectiveness of a symptom led self management plan.

\section{Methods}

The study was carried out in a nurse run asthma clinic in this general practice. ${ }^{10}$ Aylsham is a market town in rural Norfolk. The study practice of four partners and a trainee had a mid-year population in 1987 of 8049 patients. As part of a trainee project, agreed by all the partners, letters were sent to all the patients on the repeat prescribing register who were receiving prophylactic treatment for asthma. They were invited to make an appointment with one of the practice nurses. Asthma clinics were run by the nurse alone using an appointment system on three afternoons (a total of 10 hours) a week.

Patients were allocated by a random numbers chart into a peak flow group and symptoms only group. Figure 1 shows the self management plan of the peak flow group, who were asked to buy a peak flow meter, and figure 2 that of the symptoms only group. The nurse instructed each patient in the methods to be used in carrying out the two self management plans. 


\section{Symptoms only self management plan What to do and when}

- When you feel normal

Continue maintenance treatment:

(a) Bronchodilator two times a day or when needed

(b) Inhaled steroid two times a day

- If you get a cold or start to feel tight

Use your bronchodilator two puffs every four hours

- If you wake with wheezing at night or have a persistent cough

(1) Double dose of inhaled steroid for number of days it takes you to return to normal

(2) Use bronchodilator two puffs every four hours

- If your bronchodilator only lasts two hours and you find doing your normal activities makes you short of breath

(1) Start oral prednisolone $40 \mathrm{mg}$ daily $(20 \mathrm{mg}$ daily for children) and contact general practitioner

(2) Continue to use this dose for the number of days required to return you to normal

(3) Reduce oral prednisolone to $20 \mathrm{mg}$ daily

( $10 \mathrm{mg}$ daily for children) for same number of days

(4) Stop prednisolone

- If your bronchodilator lasts only 30 minutes or you have difficulty talking call the doctor immediately

FIG 2-Symptoms only self management plan developed by one of us (IC)

The first interview usually took 45 minutes. One week later the patients were reviewed by the nurse for a further 15 minutes, when spirometry was again performed and inhaler technique checked. Progress with self monitoring and self management were checked and treatment altered, if necessary, after discussion with the patient's general practitioner. Topics such as smoking, holidays, provoking factors, and emergency treatments were discussed in the course of the follow up visits. All the patients were reviewed every eight weeks by the nurse or more often if she considered it necessary.

\section{DATA ANALYSIS}

Patients' degree of illness was measured in terms of the number of consultations with the doctor, the number of courses of oral steroids, and the number of acute treatments with nebulised salbutamol. This information was extracted from the patients' records for the 12 months before they attended the clinic and during the first 12 months of attendance at the clinic. The changes within the two groups before and after the clinic were analysed with the Wilcoxon signed rank test; the differences between the two groups were analysed with the Mann-Whitney U test. The analyses were repeated for children ( $\leqslant 16$ years) and adults.

Data were also classified dichotomously into the number of patients who did or did not consult the doctor, who required or did not require courses of oral steroids, and who required or did not require short term treatments with nebulised salbutamol. Changes within the two self management groups before and after the asthma clinic were analysed with McNemar's test and $\chi^{2}$ values were used to analyse the differences between the groups. The analyses were also repeated for the children and adults.

Data were analysed with the statistical package for the social sciences program for personal computers $(\mathrm{SPSS} / \mathrm{PC}+)^{11}$ and the Minitab statistical package. ${ }^{12}$

\section{Results}

In all, 115 patients ( 51 in the peak flow and 64 in the symptoms only group) attended the asthma clinic. Forty six were children (19 in the peak flow group, 27 in the symptoms only group) and 69 adults. Patients who required maintenance treatment with steroids or nebulised salbutamol during the study were not included in the relevant analyses. Tables I and II present the results of analysing the dichotomously classified data and tables III and IV those of analysing the number of consultations, courses, and nebulised treatments.

\section{DICHOTOMOUSLY CLASSIFIED DATA}

Table I shows the numbers of patients requiring consultation with a doctor, courses of oral steroids, and short term nebulised salbutamol in the two groups before and after the formation of the asthma clinic.

All patients-Over a period of 24 months the proportion of patients needing to consult a doctor for asthma in the peak flow group fell significantly from $98 \%$ $(50 / 51)$ to $66 \%(34 / 51)(\mathrm{p}<0.001)$. In the symptoms only group over a similar period the proportion fell significantly from $97 \%(62 / 64)$ to $53 \%(34 / 64)$ $(\mathrm{p}<0.001)$. The estimated difference between the two groups was not, however, significant $(p=0.59)$ (table II). The proportion of patients receiving oral steroids in the peak flow group fell significantly from $73 \%$

TABLE I-Comparisons within peak flow and symptoms only groups of number of patients requiring doctor consultation, courses of oral steroids, and short term nebulised salbutamol before and after formation of asthma clinic

\begin{tabular}{|c|c|c|c|c|c|c|c|c|}
\hline & Group & $\begin{array}{l}\text { Neither before } \\
\text { nor after clinic }\end{array}$ & $\begin{array}{l}\text { Before but not } \\
\text { after clinic }\end{array}$ & $\begin{array}{l}\text { After but not } \\
\text { before clinic }\end{array}$ & $\begin{array}{l}\text { Before and } \\
\text { after clinic }\end{array}$ & $\begin{array}{l}\text { Observed difference in } \\
\text { proportions of after - before } \\
(95 \% \text { confidence interval) }\end{array}$ & McNemar's $\chi^{2}$ & $\mathrm{p}$ Value \\
\hline Doctor consultation & $\begin{array}{l}\text { Peak flow } \\
\text { Symptoms only }\end{array}$ & $\begin{array}{l}3 \\
1\end{array}$ & $\begin{array}{l}16 \\
29\end{array}$ & $\begin{array}{c}\text { All patients } \\
1 \\
2\end{array}$ & $\begin{array}{l}31 \\
32\end{array}$ & $\begin{array}{l}-0.29(-0.33 \text { to }-0.14) \\
-0.42(-0.56 \text { to }-0.29)\end{array}$ & $\begin{array}{l}13 \cdot 24 \\
23 \cdot 52\end{array}$ & $\begin{array}{l}<0.001 \\
<0.001\end{array}$ \\
\hline Oral steroids & $\begin{array}{l}\text { Peak flow } \\
\text { Symptoms only }\end{array}$ & $\begin{array}{l}10 \\
29\end{array}$ & $\begin{array}{l}16 \\
24\end{array}$ & $\begin{array}{l}5 \\
5\end{array}$ & $\begin{array}{r}15 \\
2\end{array}$ & $\begin{array}{l}-0.24(-0.42 \text { to }-0.06) \\
-0.32(-0.47 \text { to }-0.16)\end{array}$ & $\begin{array}{r}5 \cdot 76 \\
12 \cdot 45\end{array}$ & $\begin{array}{c}0.02 \\
<0.001\end{array}$ \\
\hline Nebulised salbutamol & $\begin{array}{l}\text { Peak flow } \\
\text { Symptoms only }\end{array}$ & $\begin{array}{l}30 \\
56\end{array}$ & $\begin{array}{r}10 \\
6\end{array}$ & $\begin{array}{l}2 \\
2\end{array}$ & $\begin{array}{l}3 \\
0\end{array}$ & $\begin{array}{l}-0.18(-0.26 \text { to }-0.01) \\
-0.06(-0.12 \text { to } 0.04)\end{array}$ & $\begin{array}{l}5 \cdot 33 \\
2 \cdot 00\end{array}$ & $\begin{array}{l}0.02 \\
0 \cdot 16\end{array}$ \\
\hline Doctor consultation & $\begin{array}{l}\text { Peak flow } \\
\text { Symptoms only }\end{array}$ & $\begin{array}{l}3 \\
1\end{array}$ & $\begin{array}{l}11 \\
13\end{array}$ & $\begin{array}{c}\text { Adults } \\
1 \\
2\end{array}$ & $\begin{array}{l}17 \\
21\end{array}$ & $\begin{array}{l}-0.31(-0.37 \text { to }-0.09) \\
-0.30(-0.39 \text { to }-0.08)\end{array}$ & $\begin{array}{l}8 \cdot 33 \\
8 \cdot 07\end{array}$ & $\begin{array}{l}<0.01 \\
<0.01\end{array}$ \\
\hline Oral steroids & $\begin{array}{l}\text { Peak flow } \\
\text { Symptoms only }\end{array}$ & $\begin{array}{r}4 \\
13\end{array}$ & $\begin{array}{l}10 \\
13\end{array}$ & $\begin{array}{l}4 \\
2\end{array}$ & $\begin{array}{l}9 \\
5\end{array}$ & $\begin{array}{l}-0.22(-0.43 \text { to } 0.08) \\
-0.33(-0.44 \text { to }-0.09)\end{array}$ & $\begin{array}{l}2 \cdot 57 \\
8 \cdot 07\end{array}$ & $\begin{array}{r}0.11 \\
<0.01\end{array}$ \\
\hline Nebulised salbutamol & $\begin{array}{l}\text { Peak flow } \\
\text { Symptoms only }\end{array}$ & $\begin{array}{l}21 \\
33\end{array}$ & $\begin{array}{l}4 \\
2\end{array}$ & $\begin{array}{l}1 \\
2\end{array}$ & $\begin{array}{l}2 \\
0\end{array}$ & $\begin{array}{r}-0.11(-0.18 \text { to } 0.08) \\
0.00(-0.09 \text { to } 0.09)\end{array}$ & $\begin{array}{l}1.08 \\
0.00\end{array}$ & $\begin{array}{l}0 \cdot 18 \\
1 \cdot 00\end{array}$ \\
\hline Doctor consultation & $\begin{array}{l}\text { Peak flow } \\
\text { Symptoms only }\end{array}$ & $\begin{array}{l}0 \\
0\end{array}$ & $\begin{array}{r}5 \\
16\end{array}$ & $\begin{array}{c}\text { Children } \\
0 \\
0\end{array}$ & $\begin{array}{l}14 \\
11\end{array}$ & $\begin{array}{l}-0.26(-0.26 \text { to } 0.01) \\
-0.59(-0.59 \text { to }-0.35)\end{array}$ & $\begin{array}{r}5 \cdot 00 \\
16 \cdot 00\end{array}$ & $\begin{array}{c}0.03 \\
<0.001\end{array}$ \\
\hline Oral steroids & $\begin{array}{l}\text { Peak flow } \\
\text { Symptoms only }\end{array}$ & $\begin{array}{r}6 \\
16\end{array}$ & $\begin{array}{r}6 \\
11\end{array}$ & $\begin{array}{l}1 \\
0\end{array}$ & $\begin{array}{l}6 \\
0\end{array}$ & $\begin{array}{l}-0.26(-0.37 \text { to } 0.06) \\
-0.41(-0.41 \text { to }-0.18)\end{array}$ & $\begin{array}{r}3 \cdot 57 \\
11 \cdot 00\end{array}$ & $\begin{array}{c}0.06 \\
<0.001\end{array}$ \\
\hline Nebulised salbutamol & $\left\{\begin{array}{l}\text { Peak flow } \\
\text { Symptoms only }\end{array}\right.$ & $\begin{array}{r}9 \\
23\end{array}$ & $\begin{array}{l}6 \\
4\end{array}$ & $\begin{array}{l}1 \\
0\end{array}$ & $\begin{array}{l}1 \\
0\end{array}$ & $\begin{array}{l}-0.29(-0.41 \text { to } 0.06) \\
-0.15(-0.15 \text { to } 0.03)\end{array}$ & $\begin{array}{l}3 \cdot 57 \\
4 \cdot 00\end{array}$ & $\begin{array}{l}0.06 \\
0.05\end{array}$ \\
\hline
\end{tabular}


(34/46) to $47 \%(21 / 46)(p=0 \cdot 02)$. In the symptoms only group this proportion also fell significantly from $52 \%$ $(31 / 60)$ to $12 \%(7 / 60)(\mathrm{p}<0.001)$, but the difference between the two groups was not significant $(p=0 \cdot 26)$ (table II). The proportion of patients requiring nebulised salbutamol fell significantly from $33 \%(15 / 45)$ to $11 \%(5 / 45)$ in the peak flow group $(\mathrm{p}=0.02)$, but the fall in the symptoms only group from $9 \%(6 / 64)$ to $3 \%$ $(2 / 64)$ was not significant $(p=0 \cdot 16)$. The difference between the two groups with the $\chi^{2}$ test was also not significant $(p=0.91)$.

Adults - The proportion of adults needing to consult a doctor for asthma in the peak flow group fell significantly from $97 \%(31 / 32)$ to $62 \%(20 / 32)(\mathrm{p}<0.01)$. In the symptoms only group the proportion fell significantly from $95 \%(35 / 37)$ to $62 \%(23 / 37)(\mathrm{p}<0.01)$. The difference between the two groups was not, however, significant $(p=0.84)$ (table II). The proportion receiving oral steroids fell from $81 \%(22 / 27)$ to $51 \%(14 / 27)$, which was not significant in the peak flow group $(p=0 \cdot 11)$, but in the other group the fall from $63 \%(21 / 33)$ to $21 \%(7 / 33)$ was significant $(\mathrm{p}<0 \cdot 01)$. The difference between the two groups was not significant $(p=0.58)$. The proportion of adults requiring nebulised salbutamol fell from $25 \%(7 / 28)$ to $11 \%$ $(3 / 28)$ in the peak flow group $(p=0 \cdot 11)$, but it remained stable at $5 \%(2 / 37)$ in the symptoms only group. The difference between the two groups was not significant $(\mathrm{p}=0 \cdot 81)$.

Children-The proportion of children requiring a consultation with a doctor for asthma fell significantly from $100 \%(19 / 19)$ to $74 \%(14 / 19)(p=0.03)$ in the peak flow group and from $100 \%(27 / 27)$ to $41 \%(11 / 27)$

TABLE II-Comparison between peak flow and symptoms only groups of changes in number of patients requiring doctor consultation, courses of oral steroids, and short term nebulised salbutamol

\begin{tabular}{|c|c|c|c|c|}
\hline & $\begin{array}{c}\text { Difference in } \\
\text { proportions between } \\
\text { groups ( } 95 \% \\
\text { confidence interval) }\end{array}$ & $\begin{array}{l}\chi^{2} \text { With } \\
\text { Yates's } \\
\text { correction } \\
\text { factor } \\
\end{array}$ & $\begin{array}{l}\text { Degrees } \\
\text { of } \\
\text { freedom p }\end{array}$ & \\
\hline & All patients & & & \\
\hline Doctor consultation & $0.00(-0.14$ to 0.15$)$ & $0 \cdot 30$ & 1 & 0.59 \\
\hline Oral steroids & $-0.16(-0.37$ to 0.0 & $1 \cdot 28$ & 1 & $0 \cdot 26$ \\
\hline \multirow{2}{*}{ Nebulised salbutamol } & $0.08(-0.28$ to 0.45$)$ & 0.01 & 1 & 0.91 \\
\hline & Adults & & & \\
\hline Doctor consultation & $0.05(-0.18$ to 0.28$)$ & 0.04 & 1 & $0 \cdot 84$ \\
\hline Oral steroids & $-0.15(-0.44$ to 0.14$)$ & 0.3 & 1 & 0.58 \\
\hline \multirow[t]{2}{*}{ Nebulised salbutamol } & $0.30(-0.30$ to 0.90$)$ & 0.06 & 1 & 0.81 \\
\hline & Children & & & \\
\hline Doctor & $0.00(0.00$ to 0.00$)$ & $0 \cdot 00$ & 1 & $1 \cdot 00$ \\
\hline Oral steroids & $-0.14(-0.40$ to $0 \cdot 12)$ & 0.06 & 1 & 0.81 \\
\hline Nebulised salbutamol & $-0.14(-0.40$ to 0.12$)$ & 0.09 & $i$ & 0.77 \\
\hline
\end{tabular}

$(\mathrm{p}<0.001)$ in the symptoms only group. Table II shows that the difference between the two groups was not significant $(\mathrm{p}=10)$. The proportion receiving oral steroids fell from $63 \%(12 / 19)$ to $37 \%(7 / 19)$ in the peak flow group, which was not significant $(\mathrm{p}=0.06)$, but it fell significantly from $41 \%(11 / 27)$ to $0 \%(0 / 27)$ $(p<0.001)$ in the symptoms only group. The difference between the two groups was not significant $(p=0 \cdot 81)$. The proportion of children requiring nebulised salbutamol fell from $41 \%(7 / 17)$ to $12 \%(2 / 17)$. This was almost a significant fall $(p=0 \cdot 06)$. The change was significant in the other group, being from $15 \%(4 / 27)$ to $0 \%(0 / 27)(p=0 \cdot 05)$. Again the difference between the two groups was not significant $(p=0.77)$.

\section{NUMBERS OF CONSULTATIONS, COURSES, AND} TREATMENTS

Table III shows the number of consultations with doctors, courses of oral steroids, and short term nebulised salbutamol treatments per patient per year in the two groups and the changes with the formation of the asthma clinic.

All patients-In the peak flow group the median number of asthma consultations with the doctor fell significantly from 8.0 to $2 \cdot 0$ consultations per patient per year $(p<0.001)$, and the fall in the symptoms only group from 4.5 to 1.0 consultations per patient per year was also significant $(p<0.001)$. The result of the Mann-Whitney $U$ test comparing the difference between the two groups was not significant $(p=0 \cdot 78)$ (table IV). The median number of courses of oral steroids fell significantly in both groups but the difference between the two groups with the MannWhitney $U$ test was not significant $(p=0.31)$ (table IV). The median number of nebulised salbutamol treatments in the peak flow group fell significantly $(p<0.01)$, but the fall was not significant in the other group $(p=0.08)$. The difference between the two groups was not significant $(p=0.09)$ (table IV).

Adults-The median number of asthma consultations with the doctor and number of courses of oral steroids fell significantly for the adult patients in both groups, but the differences between the two groups were not significant (table IV). In both groups the median number of nebulised salbutamol treatments did not fall significantly, but again the difference between the groups was not significant by the MannWhitney U test.

Children-The median number of asthma consultations with the doctor for each child fell significantly in

TABLE III-Comparisons within peak flow and symptoms only groups of changes in number of doctor consultations, courses of oral steroids, and short term nebulised salbutamol treatments before and after formation. of asthma clinic

\begin{tabular}{|c|c|c|c|c|c|c|}
\hline & \multirow[b]{2}{*}{ Group } & \multicolumn{2}{|c|}{ Median (interquartile range) } & \multirow{2}{*}{$\begin{array}{c}\text { Estimated difference } \\
\text { of after-before } \\
\text { (95\% confidence } \\
\text { interval) }\end{array}$} & \multirow{2}{*}{$\begin{array}{l}\text { Wilcoxon } \\
\text { signed } \\
\text { rank sum } \\
\text { test }\end{array}$} & \multirow[b]{2}{*}{$\mathrm{p}$ Value } \\
\hline & & $\begin{array}{l}12 \text { months } \\
\text { before clinic }\end{array}$ & $\begin{array}{l}12 \text { months } \\
\text { after clinic }\end{array}$ & & & \\
\hline Doctor consultations & $\left\{\begin{array}{l}\text { Peak flow }(n=51) \\
\text { Symptoms only }(n=64)\end{array}\right.$ & $\begin{array}{l}\quad \text { All patients } \\
8 \cdot 0(5 \cdot 0 \text { to } 12 \cdot 0) \\
4 \cdot 5(2 \cdot 0 \text { to } 8 \cdot 0)\end{array}$ & $\begin{array}{l}2 \cdot 0(0 \cdot 0 \text { to } 8 \cdot 0) \\
1 \cdot 0(0 \cdot 0 \text { to } 2 \cdot 0)\end{array}$ & $\begin{array}{l}-4 \cdot 0(-5 \cdot 5 \text { to }-2 \cdot 0) \\
-3 \cdot 5(-4 \cdot 5 \text { to }-2 \cdot 5)\end{array}$ & $\begin{array}{l}234 \cdot 5 \\
145 \cdot 0\end{array}$ & $\begin{array}{l}<0 \cdot 001 \\
<0.001\end{array}$ \\
\hline Oral steroids & $\left\{\begin{array}{l}\text { Peak flow }(n=46) \\
\text { Symptoms only }(n=60)\end{array}\right.$ & $\begin{array}{l}1.0(0.0 \text { to } 3.0) \\
0.0(0.0 \text { to } 2.0)\end{array}$ & $\begin{array}{l}0.0(0.0 \text { to } 2.0) \\
0.0(0.0 \text { to } 0.0)\end{array}$ & $\begin{array}{l}-1.0(-1.5 \text { to }-0.5) \\
-0.5(-1.0 \text { to }-0.5)\end{array}$ & $\begin{array}{r}131 \cdot 0 \\
15 \cdot 0\end{array}$ & $\begin{array}{l}<0.01 \\
<0.001\end{array}$ \\
\hline Nebulised salbutamol & $\left\{\begin{array}{l}\text { Peak flow }(n=45) \\
\text { Symptoms only }(n=64)\end{array}\right.$ & $\begin{array}{l}0.0(0.0 \text { to } 1.0) \\
0.0(0.0 \text { to } 0.0)\end{array}$ & $\begin{array}{l}0.0(0.0 \text { to } 0.0) \\
0.0(0.0 \text { to } 0.0)\end{array}$ & $\begin{array}{l}0 \cdot 0(-0 \cdot 5 \text { to } 0 \cdot 0) \\
0 \cdot 0(0 \cdot 0 \text { to } 0 \cdot 0)\end{array}$ & $\begin{array}{r}13 \cdot 5 \\
5 \cdot 0\end{array}$ & $\begin{array}{r}<0 \cdot 01 \\
0.08\end{array}$ \\
\hline Doctor consultations & $\left\{\begin{array}{l}\text { Peak flow }(n=32) \\
\text { Symptoms only }(n=37)\end{array}\right.$ & $\begin{array}{r}\text { Adults } \\
8 \cdot 0(4 \cdot 0 \text { to } 13 \cdot 5) \\
3 \cdot 0(2 \cdot 0 \text { to } 6 \cdot 0)\end{array}$ & $\begin{array}{l}2.0(0.0 \text { to } 11.8) \\
1.0(0.0 \text { to } 3.0)\end{array}$ & $\begin{array}{l}-3 \cdot 5(-5 \cdot 5 \text { to }-1 \cdot 0) \\
-2 \cdot 0(-3 \cdot 0 \text { to }-1 \cdot 0)\end{array}$ & $\begin{array}{r}100 \cdot 5 \\
99 \cdot 5\end{array}$ & $\begin{array}{r}0.01 \\
<0.01\end{array}$ \\
\hline Oral steroids & $\left\{\begin{array}{l}\text { Peak flow }(n=27) \\
\text { Symptoms only }(n=33)\end{array}\right.$ & $\begin{array}{l}2 \cdot 0(0 \cdot 0 \text { to } 4 \cdot 0) \\
1 \cdot 0(0 \cdot 0 \text { to } 2 \cdot 0)\end{array}$ & $\begin{array}{l}0.0(0.0 \text { to } 2.0) \\
0.0(0.0 \text { to } 0.0)\end{array}$ & $\begin{array}{l}-1.5(-3.0 \text { to } 0.5) \\
-1.0(-1.5 \text { to }-0.5)\end{array}$ & $\begin{array}{l}54 \cdot 0 \\
10 \cdot 0\end{array}$ & $\begin{array}{l}0 \cdot 01 \\
0 \cdot 001\end{array}$ \\
\hline Nebulised salbutamol & $\left\{\begin{array}{l}\text { Peak flow }(n=28) \\
\text { Symptoms only }(n=37)\end{array}\right.$ & $\begin{array}{l}0.0(0.0 \text { to } 0.0) \\
0.0(0.0 \text { to } 0.0)\end{array}$ & $\begin{array}{l}0.0(0.0 \text { to } 0.0) \\
0.0(0.0 \text { to } 0.0)\end{array}$ & $\begin{array}{l}0.0(-0.5 \text { to }-0.0) \\
0.0(0.0 \text { to } 0.0)\end{array}$ & $\begin{array}{l}5 \cdot 0 \\
3 \cdot 0\end{array}$ & $\begin{array}{l}0 \cdot 15 \\
0 \cdot 58\end{array}$ \\
\hline Doctor consultations & $\left\{\begin{array}{l}\text { Peak flow }(n=19) \\
\text { Symptoms only }(n=27)\end{array}\right.$ & $\begin{array}{l}\quad \text { Children } \\
7 \cdot 0(5 \cdot 0 \text { to } 10 \cdot 0) \\
6 \cdot 0(4 \cdot 0 \text { to } 9 \cdot 0)\end{array}$ & $\begin{array}{l}2.0(0.0 \text { to } 7.0) \\
0.0(0.0 \text { to } 2.0)\end{array}$ & $\begin{array}{l}-4.0(-6.5 \text { to }-1.5) \\
-5.5(-6.5 \text { to }-4.0)\end{array}$ & $\begin{array}{r}29 \cdot 0 \\
1 \cdot 5\end{array}$ & $\begin{array}{c}0.02 \\
<0.001\end{array}$ \\
\hline Oral steroids & $\left\{\begin{array}{l}\text { Peak flow }(n=19) \\
\text { Symptoms only }(n=27)\end{array}\right.$ & $\begin{array}{l}1.0(0.0 \text { to } 3 \cdot 0) \\
0.0(0.0 \text { to } 1.0)\end{array}$ & $\begin{array}{l}0.0(0.0 \text { to } 1.0) \\
0.0(0.0 \text { to } 0.0)\end{array}$ & $\begin{array}{l}-0.5(-1.5 \text { to } 0.0) \\
-0.5(-1.5 \text { to } 0.0)\end{array}$ & $\begin{array}{r}17 \cdot 5 \\
0 \cdot 0\end{array}$ & $\begin{array}{r}0.06 \\
<0.01\end{array}$ \\
\hline Nebulised salbutamol & $\left\{\begin{array}{l}\text { Peak flow }(n=17) \\
\text { Symptoms only }(n=27)\end{array}\right.$ & $\begin{array}{l}0.0(0.0 \text { to } 1.5) \\
0.0(0.0 \text { to } 0.0)\end{array}$ & $\begin{array}{l}0.0(0.0 \text { to } 0.0) \\
0.0(0.0 \text { to } 0.0)\end{array}$ & $\begin{array}{c}-0.5(-1.5 \text { to } 0.0) \\
0.0(0.0 \text { to } 0.0)\end{array}$ & $\begin{array}{l}2 \cdot 5 \\
0 \cdot 0\end{array}$ & $\begin{array}{l}0 \cdot 04 \\
0 \cdot 10\end{array}$ \\
\hline
\end{tabular}




\begin{tabular}{|c|c|c|c|c|c|}
\hline & Group & $\begin{array}{l}\text { Median difference } \\
\text { after-before } \\
\text { (interquartile range) }\end{array}$ & $\begin{array}{c}\text { Estimated difference } \\
\text { of peak flow- } \\
\text { symptoms only } \\
\text { ( } 95 \% \text { confidence interval) }\end{array}$ & $\begin{array}{l}\text { Mann-Whitney } \\
\text { U test statistic }\end{array}$ & $\mathrm{p}$ Value \\
\hline Doctor consultations & $\begin{array}{l}\text { Peak flow }(n=51) \\
\text { Symptoms only }(n=64)\end{array}$ & $\begin{array}{l}\text { All patients } \\
\quad-4 \cdot 0(-8 \cdot 0 \text { to } 0 \cdot 0) \\
\quad-3 \cdot 0(-6 \cdot 0 \text { to }-1 \cdot 0)\end{array}$ & $0.0(-2.0$ to 1.0$)$ & $2909 \cdot 0$ & $0 \cdot 78$ \\
\hline Oral steroids & $\begin{array}{l}\text { Peak flow }(n=46) \\
\text { Symptoms only }(n=60)\end{array}$ & $\begin{array}{r}-1.0(-2.0 \text { to } 0.0) \\
0.0(-1.8 \text { to } 0.0)\end{array}$ & $0.0(-1.0$ to 0.0$)$ & $2306 \cdot 5$ & $0 \cdot 31$ \\
\hline Nebulised salbutamol & $\begin{array}{l}\text { Peak flow }(n=45) \\
\text { Symptoms only }(n=64)\end{array}$ & $\begin{array}{l}0.0(-1.0 \text { to } 0.0) \\
0.0(0.0 \text { to } 0.0)\end{array}$ & $0.0(0.0$ to 0.0$)$ & $2275 \cdot 0$ & 0.09 \\
\hline Doctor consultations & $\begin{array}{l}\text { Peak flow }(n=32) \\
\text { Symptoms only }(n=37)\end{array}$ & $\begin{array}{l}\text { Adults } \\
-3 \cdot 5(-8 \cdot 0 \text { to } 0 \cdot 0) \\
-2 \cdot 0(-3.5 \text { to } 0.0)\end{array}$ & $-1 \cdot 0(-4 \cdot 0$ to $1 \cdot 0)$ & $1021 \cdot 0$ & $0 \cdot 23$ \\
\hline Oral steroids & $\begin{array}{l}\text { Peak flow }(n=27) \\
\text { Symptoms only }(n=33)\end{array}$ & $\begin{array}{r}-1 \cdot 0(-3.0 \text { to } 0.0) \\
0.0(-2 \cdot 0 \text { to } 0.0)\end{array}$ & $-1 \cdot 0(-1.0$ to 0.0$)$ & $735 \cdot 5$ & $0 \cdot 18$ \\
\hline Nebulised salbutamol & $\left\{\begin{array}{l}\text { Peak flow }(n=28) \\
\text { Symptoms only }(n=37)\end{array}\right.$ & $\begin{array}{l}0 \cdot 0(0 \cdot 0 \text { to } 0 \cdot 0) \\
0 \cdot 0(0.0 \text { to } 0 \cdot 0)\end{array}$ & $0.0(0.0$ to 0.0$)$ & $872 \cdot 5$ & $0 \cdot 30$ \\
\hline Doctor consultations & $\left\{\begin{array}{l}\text { Peak flow }(n=19) \\
\text { Symptoms only }(n=27)\end{array}\right.$ & $\begin{array}{l}\text { Children } \\
-5 \cdot 0(-6 \cdot 0 \text { to }-2 \cdot 0) \\
-6 \cdot 0(-7 \cdot 0 \text { to }-3 \cdot 0)\end{array}$ & $1.0(-1 \cdot 0$ to $4 \cdot 0)$ & $504 \cdot 5$ & $0 \cdot 20$ \\
\hline Oral steroids & $\begin{array}{l}\text { Peak flow }(n=19) \\
\text { Symptoms only }(n=27)\end{array}$ & $\begin{array}{r}-1 \cdot 0(-2 \cdot 0 \text { to } 0 \cdot 0) \\
0 \cdot 0(-1 \cdot 0 \text { to } 0 \cdot 0)\end{array}$ & $0.0(-1.0$ to 1.0$)$ & $450 \cdot 5$ & 0.93 \\
\hline Nebulised salbutamol & $\begin{array}{l}\text { Peak flow }(n=17) \\
\text { Symptoms only }(n=27)\end{array}$ & $\begin{array}{l}0 \cdot 0(-1 \cdot 5 \text { to } 0 \cdot 0) \\
0 \cdot 0(0 \cdot 0 \text { to } 0 \cdot 0)\end{array}$ & $0.0(-1.0$ to 0.0$)$ & $329 \cdot 5$ & $0 \cdot 11$ \\
\hline
\end{tabular}

both groups; the result of the Mann-Whitney U test comparing the difference between the two groups was not significant $(p=0 \cdot 20)$ (table IV). The fall in the median number of courses of oral steroids just failed to reach significance in the peak flow group $(p=0.06)$, and in the symptoms only group it was significant $(p<0 \cdot 01)$. The difference between the two groups was not significant $(p=0.93)$. The median number of nebulised salbutamol treatments fell significantly in the peak flow group but not in the symptoms only group. The difference between the two groups, however, was not significant $(p=0 \cdot 11)$.

\section{Discussion}

We found that self management plans for asthma can make a valuable contribution to the care of asthma but that the peak flow meter is not necessarily the key to improved illness. Although at first this may seem surprising, on reflection it is understandable. Our patients were provided with a package of care that included a specially trained nurse practitioner, longer consultation times, review of inhaler technique, regular follow up, self management plans, education, and invariably more appropriate use of inhaled steroids. Overall, the nurse run asthma clinic was associated with considerable improvements in the illness of both adults and children. Doctor consultations, the number of oral steroid courses, and the use of nebulised salbutamol fell regardless of which self management plan patients were issued with. Viewed in the light of these changes to patient care and the similarity in outcome between our two treatment groups, we think that the peak flow meters used in the context of this study did not bestow a significant advantage.

We recognise that the peak flow meter is an invaluable tool for the diagnosis and assessment of asthma in general practice. Its widespread distribution may not, however, be the only method by which the illness from asthma can be reduced. The possibility that a symptoms only self management plan, effectively administered by a nurse, can bring about a reduction in such illness in both adults and children is suggested by our results.

The cost of purchasing a peak flow meter and the ability to use it also needs consideration. Although our patients showed a willingness to purchase peak flow meters once their purpose had been fully explained, this may not be the case in other areas. Very young and very old people may have difficulty coordinating a breath to register a reproducible result. An alternative to a peak flow meter may have merit for certain groups of patients.

The similarity in outcome between our two groups may be explained by the fact that the patients were taught the importance of their symptoms through discussions with the nurse and regular checks on a spirometer. A study by Rubinfield and Pain found that $15 \%$ of patients were unaware of the degree of their airways obstruction. ${ }^{7}$ Sibbald found that $17 \%$ of patients tested with a hypothetical asthma attack delayed seeking medical help despite having severe symptoms. ${ }^{12}$ Our study raises the possibility that these patients are amenable to being taught the importance of their symptoms and more appropriate self management. The results also raise the possibility that only the more severe asthmatic patients or those requiring nebulisers at home may benefit from owning their own peak flow meter. Another possibility is that lending patients a peak flow meter for a few weeks may be a satisfactory way of teaching them the importance of their symptoms, which can then form the basis for appropriate self management.

An interesting subject for future study would be to examine the points at which patients need to make changes in their treatment. We think that the patients who had the symptoms only plan actually implemented the higher dose of inhaled steroid earlier in an attack of asthma than patients who waited until their peak flow fell to $70 \%$ of normal. At $70 \%$ their asthma attack may have been well advanced and not as amenable to an increase in inhaled steroids. The earlier introduction of inhaled steroids by the symptoms only group may have led to a reduced use of oral steroids. Inhaled steroids take a few days to have their full benefit. Patients in the symptoms only self management group may have had a slightly better outcome because of an earlier introduction of inhaled steroids. This trend was evident in the study. The decrease in the percentage of all patients requiring oral steroids in the peak flow group fell from $73 \%$ to $47 \%$, a $26 \%$ reduction. The decrease in the other group was from $52 \%$ to $12 \%$, a reduction of $40 \%$. Similarly, doctor consultations in the peak flow group fell from $98 \%$ to $66 \%$, a reduction of $32 \%$, while the fall was from $97 \%$ to $53 \%$ in the symptoms only group, a reduction of $44 \%$.

For many patients in general practice who can respond to their symptoms the peak flow meter with its cut off points at $70 \%$ and $50 \%$ may have delayed their response and allowed their asthma to progress a little further, by which time oral steroids would be needed. Once patients started treatment with oral steroids they 
were advised to contact the doctor. A proportion of these patients may have sought a consultation with a doctor, rather than telephoning as we suggested, because the delay in treatment had meant that they were experiencing more asthma than usual.

In their pilot study on hospital patients Beasley et al chose $70 \%$ as the value at which to implement changes in treatment. ${ }^{9}$ Once patients have been taught the importance of their symptoms $75 \%$ or $80 \%$ may be a more appropriate criterion in general practice. Fifty per cent as the point of introducing oral steroid treatment was selected by Beașley et al because it was observed that morning dips with a fall in peak flow of more than $50 \%$ of the highest daily peak flow preceded sudden death. ${ }^{1314}$ In general practice, where the patients with asthma may not be so severely affected, a lower cut off point of $45 \%$ or possibly $40 \%$ may be appropriate. This may reduce the use of oral steroids but increase the need for treatment with nebulised drugs and time lost from work and school. The earlier introduction of inhaled steroids may help compensate for this effect.

The study was carried out on a population of both adults and children. The analysis showed no major differences between the two. This confirms our belief that a standard self management plan whether directed by symptoms or peak flows is applicable to children and adults alike.

The peak flow meter has a well established place in the care of asthma. Peak flow meters are soon to be available on prescription in the NHS. It is a timely reminder that simply prescribing peak flow meters without a system of self management and regular review will be unlikely to improve patient care. Techniques that teach the patients the importance and relevance of their symptoms and how to implement changes in management are vitally important if asthma care is to be improved.

Our study raises some interesting questions about the use of peak flow meters in general practice. In an attempt to overcome some of these problems we have developed a colour coded peak flow meter ${ }^{15}$ which helps the patient easily learn the concepts of self management and modify treatment appropriately. Such a system together with modified cut off points may well help the meter play an important part in the long term management of asthma in general practice.

We thank the Clare Wand fund, the Scientific Foundation of the Royal College of General Practitioners, and Vitalograph for providing support funds. We thank Drs P C S Chapman, $\mathrm{J}$ L Christie, K R Harrison, and K Elsby and staff at the Aylsham surgery for their cooperation, and Professor John Bain and Dr Roger Jones of the Primary Medical Care Group at the University of Southampton for their advice throughout the study. We dedicate this paper to the late Dr David Williams, whose guidance made this project a reality.

1 Battu K, Collins-Williams C, Zaleskyey C. Evaluation of home monitoring of asthmatic children with the mini-Wright peak flow meter. $\mathcal{F}$ Asthma 1982;19:93-7.

2 Prior JG, Cochrane GM. Home monitoring of peak expiratory flow rate using mini-Wright peak flow meter in the diagnosis of asthma. $f R$ Soc Med 1980;73:731-3.

3 McGuinness BV. A Wright peak flow meter in practice. Practitioner 1982; 226:21.

4 Wright BM. Wright's peak flow meter. BMF 1978;ii:1627-8.

5 Anonymous. Self monitoring of peak expiratory flow rate in asthma. Drug Ther Bull 1982 Sep 17:73-4.

6 Williams AJ, Church SE. Availability of mini peak flow meters for the management of severe asthma. Lancet 1985; i:1341.

7 Rubinfield AR, Pain MCF. The perception of asthma. Lancet 1976;i:882-4.

8 Sibbald B. Patient self-care in acute asthma. Thorax 1989;44:97-101.

9 Beasley R, Cushley M. Holgate ST. A self management plan in the treatment of adult asthma. Thorax 1989;44:200-4.

10 Charlton IH, Charlton GFA, Broomfield J, Mullee M. Asthma care in general practice: evaluation of a nurse run asthma clinic. British fournal of General practice: evaluation

11 Norusis MJ. The SPSS guide to data analysis for SPSS/PC+. Chicago: SPSS, 1989.

12 Ryan BF, Joiner BL, Ryan TA. Minitab handbook. 2nd ed. Boston: Duxbury, 1985 .

13 Hetzel MR, Clark TJM, Braithwaite MA. Asthma analysis of sudden deaths and ventilatory arrests in hospital. BMF 1977;4:808-11.

14 Bateman JRM, Clarke SW. Sudden deaths in asthma. Thorax 1979;34:40-4. 15 Charlton IH, Charlton GFA. New perspectives in asthma care. Practitioner 1990;234:30-2.

(Accepted 2 October 1990)

\title{
Abuse of elderly people by their carers
}

\author{
Ann C Homer, C Gilleard
}

\begin{abstract}
Objective-To assess the prevalence of abuse of elderly people by their carers and the characteristics of abusers and the abused.

Design-Information on abuse and risk factors was collected over six months from carers and patients. Risk factors were identified in the abused group and compared with those in a non-abused control group.
\end{abstract}

Setting-Carers were interviewed at home; patients were examined in the wards of Putney and Barnes geriatric hospitals, London.

Subjects-All patients referred from any source for respite care to the geriatric services over a six month period and their carers.

Main outcome measures-Amount of physical and verbal abuse or neglect. Quantification of risk factors and correlation with the presence or absence of abuse.

Results $-45 \%$ Of carers openly admitted to some form of abuse. Few patients admitted abuse. The most significant risk factor for physical abuse was alcohol consumption by the carer $(\mathbf{p}<0 \cdot 001)$. Other significant risk factors were a poor pre-morbid relationship and previous abuse over many years. Abuse was often reciprocated and was associated with social dysfunction in many patients. Service delivery, respite care, and level of mental and physical disability were not significantly associated with abuse.

Conclusion-The high level of abuse found in elderly patients in respite care was particularly associated with alcohol abuse and long term relationships of poor quality, which are difficult to change. Even with increased provision of services, care in the community may not be the best solution for these people.

\section{Introduction}

Although "granny battering" was first described in Britain in $1975,{ }^{1}$ most of the research on abuse of elderly people has been carried out in North America, where statutory requirements to notify authorities of suspected cases facilitates identification for research purposes. The extent of this abuse is not known, but a social services survey in 1988 found 5\% of elderly clients were being abused, ${ }^{2}$ and this is comparable with 